Biol. Proced. Online 2002;4(1): 94-104.

\title{
A proteomic approach based on peptide affinity chromatography, 2-dimensional electrophoresis and mass spectrometry to identify multiprotein complexes interacting with membrane-bound receptors
}

\author{
Carine Bécamel ${ }^{1}$, Nathalie Galéotti ${ }^{1}$, Joël Poncet ${ }^{1}$, Patrick Jouin ${ }^{1}$, Aline Dumuis ${ }^{1}$, Joël \\ Bockaert $^{1}$ and Philippe Marin ${ }^{1 *}$
}

${ }^{1}$ CNRS UPR 9023, 141, Rue de la Cardonille, 34094 Montpellier Cedex 5, France.

*Corresponding author: Phone: +33 4671429 83; Fax +33 4671429 10; Email: marin@montp.inserm.fr

Submitted: September 17, 2002; Revised: November 14, 2002; Accepted: November 15, 2002; Published: December 9, 2002

Indexing terms: proteomics; spectrum analysis, mass.

\begin{abstract}
There is accumulating evidence that membrane-bound receptors interact with many intracellular proteins. Multiprotein complexes associated with ionotropic receptors have been extensively characterized, but the identification of proteins interacting with G protein-coupled receptors (GPCRs) has so far only been achieved in a piecemeal fashion, focusing on one or two protein species. We describe a method based on peptide affinity chromatography, two-dimensional electrophoresis, mass spectrometry and immunoblotting to identify the components of multiprotein complexes interacting directly or indirectly with intracellular domains of GPCRs or, more generally, any other membrane-bound receptor. Using this global approach, we have characterized multiprotein complexes that bind to the carboxy-terminal tail of the 5hydroxytryptamine type $2 \mathrm{C}$ receptor and are important for its subcellular localization in CNS cells (Bécamel et al., EMBO J., 21(10): 2332, 2002).
\end{abstract}

\section{INTRODUCTION}

Many cellular processes implicate large protein networks. The global identification of the components of these networks is essential to study their functions. There is accumulating evidence that membrane-bound receptors such as ionotropic receptors or tyrosine kinases are associated with large multiprotein complexes $(1,2)$. G-protein coupled receptors (GPCRs), which constitute one of the largest known categories of proteins, also interact with several intracellular proteins in

(C) 2002. Biological Procedures Online. Published in Biological Procedures Online under license from the author(s). Copying, printing, redistribution and storage permitted. 
interacts with a PDZ-based multiprotein complex (11). Using this approach, we have identified 15 proteins that bind directly or indirectly to the C-terminal tail of the 5- $\mathrm{HT}_{2 \mathrm{C}}$ receptor (12). These include synapse-enriched multi domain proteins containing one or several PDZ domains and proteins devoid of PDZ domains. This method, which provides a global characterization of multiprotein complexes, can thus be used for systematic identification of proteins interacting with the intracellular domains of membrane-bound receptors and of protein networks associated with any protein.

\section{MATERIALS AND METHODS}

\section{Antibodies and Plasmids}

The rabbit polyclonal anti-Veli3 antibody was purchased from Zymed Laboratories (San Francisco, CA), mouse monoclonal anti-CASK and anti-Mint1 antibodies from Becton Dinckinson Biosciences. The Veli2 antibody was obtained by immunization of rabbits with a synthetic peptide derived from the Veli2 sequence (QHHSYSSLESRG) as previously described (13). This antibody recognized a single polypeptide around $24 \mathrm{kDa}$ in Western blots of mouse brain extracts (12). Horseradish peroxidase-coupled donkey anti-rabbit and antimouse secondary antibodies were from Amersham Biosciences (Upsalla, Sweeden).

The expression vectors encoding the wild type and mutated Cterminal tail of the human 5- $\mathrm{HT}_{2 \mathrm{C}}$ receptor (residues 368-458) fused to GST (pGEX2C90SSV and pGEX902CSSA, respectively) have been described elsewhere (14).

\section{Membrane preparations and GST pull-down}

Mice brains were homogenized with a polytron in $20 \mathrm{ml}$ phosphate buffered saline (PBS) and centrifuged at $200 \mathrm{x}$ g for $5 \mathrm{~min}$. Pellets were resuspended in ice-cold lysis buffer containing Tris- $\mathrm{HCl}(50 \mathrm{mM}, \mathrm{pH} 7.4)$, EDTA (1 mM), and a protease inhibitor cocktail (Roche), homogenized 20 times on ice with a glass-Teflon homogenizer and centrifuged at 10,000 $\mathrm{x} \mathrm{g}$ for $30 \mathrm{~min}$. The membrane pellets were resuspended in

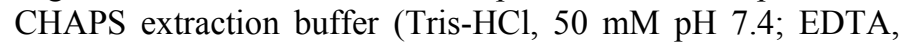
$0.05 \mathrm{mM}$; CHAPS, $10 \mathrm{mM}$ and protease inhibitors) for $3 \mathrm{~h}$ in rotation at $4^{\circ} \mathrm{C}$. Then, samples were centrifuged for $1 \mathrm{~h}$ at $10,000 \times \mathrm{g}$ and solubilized proteins (supernatants, $20 \mathrm{mg}$ protein per condition) were incubated with immobilized GSTfusion proteins overnight at $4^{\circ} \mathrm{C}$. GST and GST-fusion proteins were expressed in Escherichia coli strain BL21 and immobilized (50 $\mu \mathrm{g}$ each) on glutathione-sepharose 4B beads (Amersham Biosciences). Samples were washed five times with $150 \mathrm{mM} \mathrm{NaCl}$ and eluted with $10 \mathrm{mM}$ reduced glutathione. Samples were then precipitated with $10 \%$ ice-cold trichloroacetic acid (TCA) for $2 \mathrm{~h}$ and precipitates were washed three times with diethyl ether.

\section{Two-dimensional electrophoresis}

TCA precipitates were resuspended in $350 \mu \mathrm{l}$ isoelectrofocusing medium containing urea $(7 \mathrm{M})$, thiourea $(2$ M), CHAPS (4\% w/v), ampholines (preblended, pI 3.5-9.5, 8 $\mathrm{mg} / \mathrm{ml}$, Amersham Biosciences), dithiothreitol (DTT, 100 $\mathrm{mM})$, Tergitol NP7 $(0.2 \% \mathrm{v} / \mathrm{v}$, Sigma $)$ and traces of bromophenol blue (15). Proteins were first separated according to their isoelectric point along linear immobilized $\mathrm{pH}$-gradient (IPG) strips (pH 3-10, $18 \mathrm{~cm}$ long) using the IPGphor apparatus (Amersham Biosciences). Sample loading for the first dimension was performed by passive in-gel re-swelling. After the first dimension, the IPG strips were equilibrated for $10 \mathrm{~min}$ in a buffer containing urea $(6 \mathrm{M})$, Tris- $\mathrm{HCl}(50 \mathrm{mM}, \mathrm{pH}$ $6.8)$, glycerol $(30 \% \mathrm{v} / \mathrm{v})$, SDS $(2 \% \mathrm{w} / \mathrm{v})$, DTT $(10 \mathrm{mg} / \mathrm{ml})$ and bromophenol blue and then for $15 \mathrm{~min}$ in the same buffer containing $15 \mathrm{mg} / \mathrm{ml}$ iodoacetamide instead of DTT. For the second dimension, the strips were loaded onto vertical $12.5 \%$ SDS polyacrylamide gels. The gels were silver stained according to the procedure of Shevchenko et al. (16).

\section{Image acquisition and 2-D gel spot pattern analysis}

Gels to be compared were always processed and stained in parallel. Gels were scanned using a computer-assisted densitometer (Amersham Biosciences). Spot detection, gel alignment and spot quantification were performed using the Image Master 2-D Elite software (Amersham Biosciences). Quantitative variations of proteins were expressed as volumes of spots. To correct for variability resulting from silver staining, results were expressed as relative volumes of all spots in each gel. Data are the means of values from four gels originating from different pull-down experiments.

\section{Protein identification by MALDI-TOF mass spectrometry}

Proteins of interest were excised and digested in gel using trypsin (sequencing grade, Promega, Madison, WI), as previously described $(16,17)$. Digest products were completely dehydrated in a vacuum centrifuge and resuspended in $10 \mu \mathrm{l}$ formic acid $(2 \% \mathrm{v} / \mathrm{v})$, desalted using Zip Tips C18 (Millipore, Bedford, MA), eluted with $10 \mu \mathrm{l}$ acetonitrile:trifluoroacetic acid, (80:0.1\%) and concentrated to $2 \mu$ l. Aliquots of analyte solutions were mixed with the same volume of $\alpha$-cyano-4hydroxy-trans-cinnamic acid $(10 \quad \mathrm{mg} / \mathrm{ml} \quad$ in acetonitrile:trifluoroacetic acid, 50:0.1\%) and loaded on the target of a BIFLEX III MALDI-TOF mass spectrometer (Bruker-Franzen Analytik, Bremen, Germany) using the Drydroplet procedure (18). Analysis was performed in reflectron mode with an accelerating voltage of $20 \mathrm{kV}$ and a delayed extraction of $400 \mathrm{~ns}$. Mass spectra were acquired as the sum of the ion signals that were generated by irradiation of the target 
with a mean of 300 laser pulses. Spectra were analyzed using the XTOF software (Bruker-Franzen Analytik) and autoproteolysis products of trypsin $(\mathrm{m} / \mathrm{z}$ 842.51, 1045.56, 2211.10) were used as internal calibrates. Peptides were selected in the mass range of 800-3500 Da. Identification of proteins was performed using both Mascot and PeptIdent softwares, available online at http://www.matrixscience.com and http://www.expasy.org/tools/peptident.html, respectively. A mass deviation of $100 \mathrm{ppm}$ was allowed for data base interrogation, but the mass accuracy of our analyses was usually better than $50 \mathrm{ppm}$. Coverage of the full-length protein exceeding $15 \%$ was considered to be sufficient unless there were some obvious conflicts between the experimental molecular weight or isoelectric point and those of the identified protein (19). Matching peptides with missed cleavages were considered as pertinent only when there were two consecutive basic residues or when arginine and lysine residues were followed by a proline or acidic residues inside the peptide amino acid sequence.

\section{Protein identification by tandem mass spectrometry}

Nanoelectrospray mass spectrometry was performed on a quadrupole time-of-flight (Q-TOF) mass spectrometer (QSTAR; Sciex, Toronto, Canada) equipped with a nanospray source (Protana Inc., Odense, Denmark). The needle containing $1 \mu$ peptide mixtures, purified by using POROS R2 micro columns (Protana), was briefly touched against the interface plate and then centered in front of the mass spectrometer orifice. A potential of $900 \mathrm{~V}$ at the needle started the nanospray. Peptide fragmentation was performed in the collision cell using nitrogen gas on the doubly charged peptide ions detected, with a collision energy profile optimized individually for each peptide $(30-55 \mathrm{~V})$. Tandem mass spectra were interpreted using the BioAnalyst software (Applied BioSystems). Identification of proteins was performed by matching the experimental MS/MS spectra of multiple peptides from the same protein against calculated spectra for all peptides in a protein sequence database, using the Mascot software (http://www.matrixscience.com). For Mascot searches, a positive score was defined to be greater than 30 for each peptide ion. The identification was systematically confirmed by manual interpretation of the MS/MS spectra by the "peptide sequence tag" method using the BioAnalyst and PeptideSearch softwares (www.narrador.emblheidelberg.de) $(20,21)$.

\section{Immunoblotting}

Proteins, resolved on 1-D or 2-D gels, were transferred electrophoretically onto nitrocellulose membranes (Hybond-C, Amersham Biosciences). Membranes were incubated overnight with primary antibodies. Immunoreactivity was detected with an enhanced chemiluminescence method (Renaissance Plus, NEN DuPont, Boston, MA).

\section{RESULTS AND DISCUSSION}

Proteins interacting with the cytosolic C-terminal tail of the 5$\mathrm{HT}_{2 \mathrm{C}}$ receptor were purified by peptide affinity chromatography using the entire C-terminal tail of the receptor (90 amino acids) fused to GST (GST902CSSV) as bait. The bait $(50 \mu \mathrm{g}$ per assay) was immobilized onto glutathione sepharose beads. Whole brain extracts were used in this purification step because the $5-\mathrm{HT}_{2 \mathrm{C}}$ receptor displays a wide and discrete distribution in the central nervous system. The bound proteins were eluted, separated by 2-D electrophoresis and stained with silver. For silver staining, we used a procedure allowing further micro characterization of proteins by mass spectrometry (16). This method omits the sensitization with glutaraldehyde, which is known to make covalent bounds with proteins through Schiff base formation with amino groups, and minimizes oxidation of proteins. Fig. 1 illustrates a typical 2-D gel obtained with the GST902CSSV bait. These gels exhibited numerous protein spots, probably due to the high sensitivity of the silver staining procedure used, which detects proteins in the nanogramme range (Fig. 1). Among these proteins, several major spots were identified as GST and/or GST fusion protein by MALDI-TOF mass spectrometry (Fig. 1).

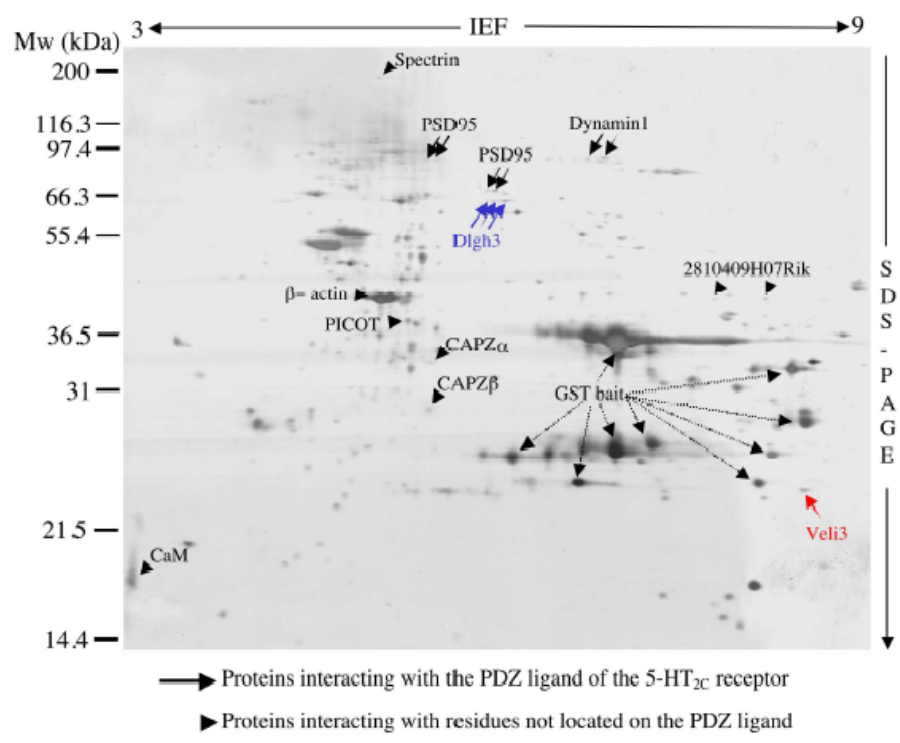

Fig. 1: Protein 2-D map of multiprotein complexes interacting with the $\mathbf{C}$ terminal extremity of the $5-\mathbf{H T}_{2 \mathrm{C}}$ receptor. Proteins interacting with the Cterminal tail of the $5-\mathrm{HT}_{2 \mathrm{C}}$ receptor were purified by peptide affinity chromatography on glutathione sepharose beads using the C-terminal 90 amino acid residues of the receptor (GST902CSSV) as bait. Proteins, recovered with reduced glutathione, were resolved on 2-D gels and stained with silver. A representative gel is illustrated. Arrows and arrowheads indicate protein spots that were not detectable (or much less represented) in gels obtained using the GST902CSSA and GST baits, respectively. The unlabelled spots were found in equal amounts in gels performed with all baits. Some of them were identified as $E$. coli proteins or major brain proteins. MALDI-TOF MS and MS/MS analyses of Veli3 (red) and Dlgh3 (blue) are described in detail on Figures 2 and 3 , respectively.

To detect proteins that specifically interact with the C-terminal 
tail of the $5-\mathrm{HT}_{2 \mathrm{C}}$ receptor, we performed differential analyses of 2-D gel protein patterns obtained with the GST902CSSV bait and two control baits: 1) GST alone and 2) GST fused to the C-terminal tail of the $5-\mathrm{HT}_{2 \mathrm{C}}$ receptor which was mutated on the C-terminal residue of the PDZ ligand (GST902CSSA). This residue is critical for the interaction with target PDZ domains (14). A comparison of protein patterns in the 2-D gels obtained with the GST902CSSV and GST902CSSA baits, indicated a selective recruitment of 5 spots or groups of spots (indicated by arrows in Fig. 1) by the wild type bait. These spots were not detectable on gels performed with the GST902CSSA bait ( $n=4$ gels originating from 4 pull-down experiments, see Figs. 2 and 3). These proteins were unambiguously identified by MALDI-TOF and/or MS/MS as four distinct proteins (Figs. 1-3). Three of them are proteins that contain one or several PDZ domains. The fourth protein that bound selectively to the wild type bait (dynamin 1) was devoid of PDZ domains, but its association with proteins containing PDZ domains has already been suggested. This protein may thus be indirectly recruited by the C-terminal tail of the $5-\mathrm{HT}_{2 \mathrm{C}}$ receptor through a PDZ domain-based scaffold. Altogether, these results validate the method used to purify and detect proteins interacting specifically with PDZ domain recognition motifs located at the C-terminal extremity of membrane-bound receptors.

$\mathbf{A}$
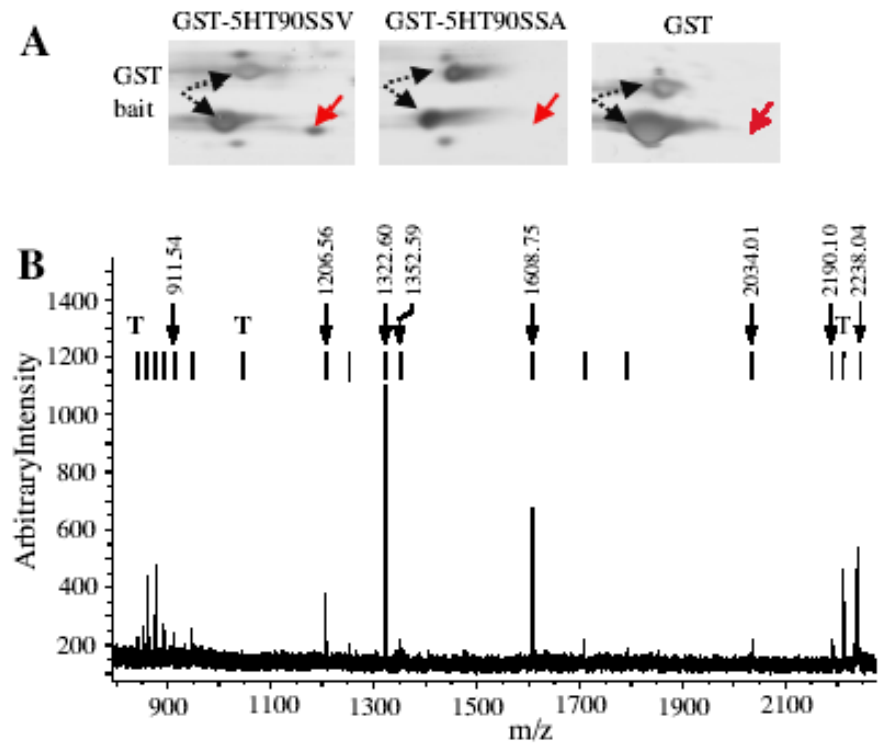

Fig. 2: MALDI-TOF mass spectrometry identification of Veli3 as a binding partner of the PDZ ligand of the 5-HT $2 \mathrm{C}$ receptor. A. Areas of interest of silver-stained 2-D gels obtained in experiments using the GST902CSSV, GST902CSSA and GST baits, respectively, and showing the specific recruitment of one protein spot by the PDZ ligand of the $5-\mathrm{HT}_{2 \mathrm{C}}$ receptor. B. MALDI-TOF peptide mass map obtained from in-gel trypsin digestion of this spot. Ion signals with measured masses that matched calculated masses of protonated tryptic peptides of mouse Veli3 are indicated. $\mathrm{T}$ indicates the ion signals corresponding to the autolysis products of trypsin that were used for internal calibration of spectra (mol wt: 842.51, 1045.56 and 2211.10 , respectively).
C Search parameters

\begin{tabular}{|c|c|}
\hline Dataluw searched & Swiss:Pror + Trembl \\
\hline Species seanched & Mas masculas \\
\hline P1 range & $9 \pm 1$ \\
\hline Mw rage & $20000 \mathrm{Da} \pm 20 \%$ \\
\hline Peptide mass folerance & $\pm 100 \mathrm{ppm}$ \\
\hline Peptide masses & Monoiscopic, $\left[\mathrm{M}+\mathrm{H}^{*}\right]$ \\
\hline Cystiax trexed wiต & bdoscetanide \\
\hline Fazyme & Trypsin \\
\hline Allow for & 1 mised ckavage site \\
\hline
\end{tabular}

\begin{tabular}{|c|c|c|c|c|c|c|}
\hline Ranik & 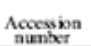 & Descriptikn & $\mathrm{P}$ & Mw & $\begin{array}{l}\text { Peptidle } \\
\text { mistass }\end{array}$ & $\begin{array}{l}\text { Contrags } \\
\text { (w/) }\end{array}$ \\
\hline $\begin{array}{l}1 \\
2 \\
2\end{array}$ & $\begin{array}{l}\text { Os852 } \\
\text { O\$8951 }\end{array}$ & $\begin{array}{l}\text { VEL13 proxin } \\
\text { VEU12 moxin }\end{array}$ & $\begin{array}{l}8.52 \\
8.71\end{array}$ & $\begin{array}{l}21.8 \\
22.9\end{array}$ & $\begin{array}{l}8 \\
3\end{array}$ & $\begin{array}{l}50 \\
14\end{array}$ \\
\hline
\end{tabular}

Adapted from http://us.expasy.org/tools/peptident .html

Fig 2C: Parameters and results of SwissProt and Trembl database search.

We also detected an enrichment of several protein species in 2$\mathrm{D}$ gels obtained in pull down experiments performed with the GST902CSSV and GST902CSSA baits, when compared with those obtained with GST alone (four gels performed in each experimental condition). These proteins are indicated by arrowheads on Fig. 1. Identical amounts of these proteins were retained by the wild type and mutated baits. These proteins that include cytoskeleton proteins as well as signaling proteins, lack obvious PDZ domains. This indicates that they interact with residues that are not located in the PDZ ligand of the receptor. The data illustrated in Fig. 1 demonstrate that the resolution provided by 2-D gel electrophoresis combined with the high sensitivity of the silver staining procedure was required to detect the proteins specifically recruited by the $5-\mathrm{HT}_{2 \mathrm{C}}$ receptor C-terminal tail. As previously mentioned, the 2-D protein pattern recovered from the GST pull down assays exhibited numerous protein spots. Some of these spots were identified as either bacterial proteins that bind to GST and/or fusion peptide during bait production in bacteria, or major proteins from mice brain. The gels also showed a large enrichment of GST baits, compared with most of the proteins identified as specific binding partners of the receptor. Separating proteins by 1-D electrophoresis would have probably precluded the detection of proteins with a molecular weight similar to that of the bait, such as the Veli3 protein (Figs. 1 and 2). Moreover, identification of proteins by MALDI-TOF mass spectrometry, which only provides peptide mass fingerprints but not sequence information, requires an efficient purification procedure such as that provided by $2-\mathrm{D}$ electrophoresis.

However, GST proteins or any other contaminating protein may mask specific binding partners of the receptor, even when proteins are separated by 2-D electrophoresis. Moreover, several limitations inherent to 2-D electrophoresis make difficult the detection and the identification of some of the proteins purified during the affinity chromatography step such as hydrophobic, basic $(\mathrm{pI}>9)$, large $(>200 \mathrm{kDa})$ and small $(<$ $10 \mathrm{kDa}$ ) proteins. An alternative approach, that combines efficient separation of biological materials and high sensitivity, associates 1-D electrophoresis and liquid chromatography (LC) coupled to MS/MS (LC-MS/MS) (21). This approach, based on 
LC separation of tryptic peptides prior to MS/MS, can theoretically analyze complicated mixtures containing up to hundreds of proteins (21), and has already been used to identify proteins physically associated to the N-methyl-D-aspartate receptor and separated by 1-D electrophoresis (1). This methodology largely removes the difficulty to identify proteins containing several trans-membrane domains and basic proteins. A procedure which do not require any gel separation and staining and based on direct trypsin digestion of proteins purified by affinity chromatography followed by LC-MS/MS analysis, would also resolve the issue of identifying large proteins as well as peptides that bind to the C-terminal tail of the receptors. This strategy has been successfully used by Ficarro et al. (22) to characterize the yeast phosphoproteome purified by affinity chromatography. However, the large variations in protein concentration in our samples (e.g. GST bait and Veli3) may render uncertain the identification of minor proteins by these alternative approaches. Moreover, our strategy based on 2-D gels remains a method of choice to perform differential analyses of protein expression.

In our experience, MALDI-TOF mass spectrometry yielded non-ambiguous identification of most of the proteins examined. Mean sequence coverage of $40 \%$ was obtained, which is a much higher score than that generally admitted (15-20\% of protein coverage) (19). Moreover, the identity of the protein was always confirmed in 2-D immunoblotting when antibodies against the identified proteins were available. The high success rate in these analyses was linked to the high mass accuracy achieved. Indeed, the deviation between experimental peptide masses and those resulting from theoretical digestion of the protein was generally inferior to $50 \mathrm{ppm}$ using trypsin autolysis peptides as internal calibrates. Another important characteristic of the MALDI-TOF technology is its ability to discriminate between closely related proteins, even when these proteins share high degrees of identity. Veli3, one of the proteins that was recruited by the C-terminal tail of the $5-\mathrm{HT}_{2 \mathrm{C}}$ receptor, belongs to a family of related proteins containing one PDZ domain and named Veli1, Veli 2 and Veli3 (for Vertebrate homologues of LIN-7) (23). Veli3 and Veli2 amino acid sequences show $81 \%$ identity. Moreover, both proteins display similar molecular weights and isoelectric points, indicating a possible overlap of both proteins on 2-D gels. The peptide masses deduced from the MALDI-TOF mass spectrum illustrated in Figure 2B only matched the theoretical peptide masses calculated for Veli3 according to the criteria defined in "Materials and Methods." Eight tryptic peptides, corresponding to the coverage of almost $50 \%$ of the sequence, were assigned to the sequence (Figure 2C). The second ranked protein was Veli2, but only 3 peptides corresponding to $14 \%$ sequence coverage were assigned to the sequence. This specific identification of Veli3 versus Veli2 as a binding partner of the $5-\mathrm{HT}_{2 \mathrm{C}}$ receptor was further confirmed by immunoblotting using specific antibodies raised against both proteins (data not shown).

The identity of several proteins recruited in our in vitro binding assay was confirmed by MS/MS. Because MS/MS spectra contain sequence information on the peptides rather than only their mass, this approach is certainly more discriminating. MS/MS analysis was systematically performed when no antibody against the protein of interest was available. It is noteworthy that in our analyses MS/MS data always confirmed the results obtained by MALDI-TOF MS. Two methods that generally provided identical results were used to identify proteins by MS/MS: 1) the match of the experimental fragmentation spectrum against the theoretical spectra of all peptides in protein databanks and 2) the sequence tag method. Peptide sequence tag combines a short sequence stretch with mass information that specifies the location of the identified sequence inside the tryptic peptide (21). These two approaches generally yielded identical results. Fig. 3 illustrates the MS/MS analysis of one of the double charged tryptic peptides $(\mathrm{m} / \mathrm{z}=$ 645.83) of Dlgh3, a protein that was identified as one of the binding partners of the PDZ ligand of the $5-\mathrm{HT}_{2 \mathrm{C}}$ receptor by MALDI-TOF MS. Comparing the experimental fragmentation spectrum (Fig. 3B) with a calculated spectrum for all peptides in the NCBI database yielded a single match with a high score and corresponding to a Dlgh3 peptide (Fig. 3C). We obtained the same unique peptide match by the peptide sequence tag (determined by interpretation of the MS/MS spectrum with the BioAnalyst software) method and Non-Redundant Protein Database interrogation using the PeptideSearch algorithm (Fig. 3D).

\section{A}
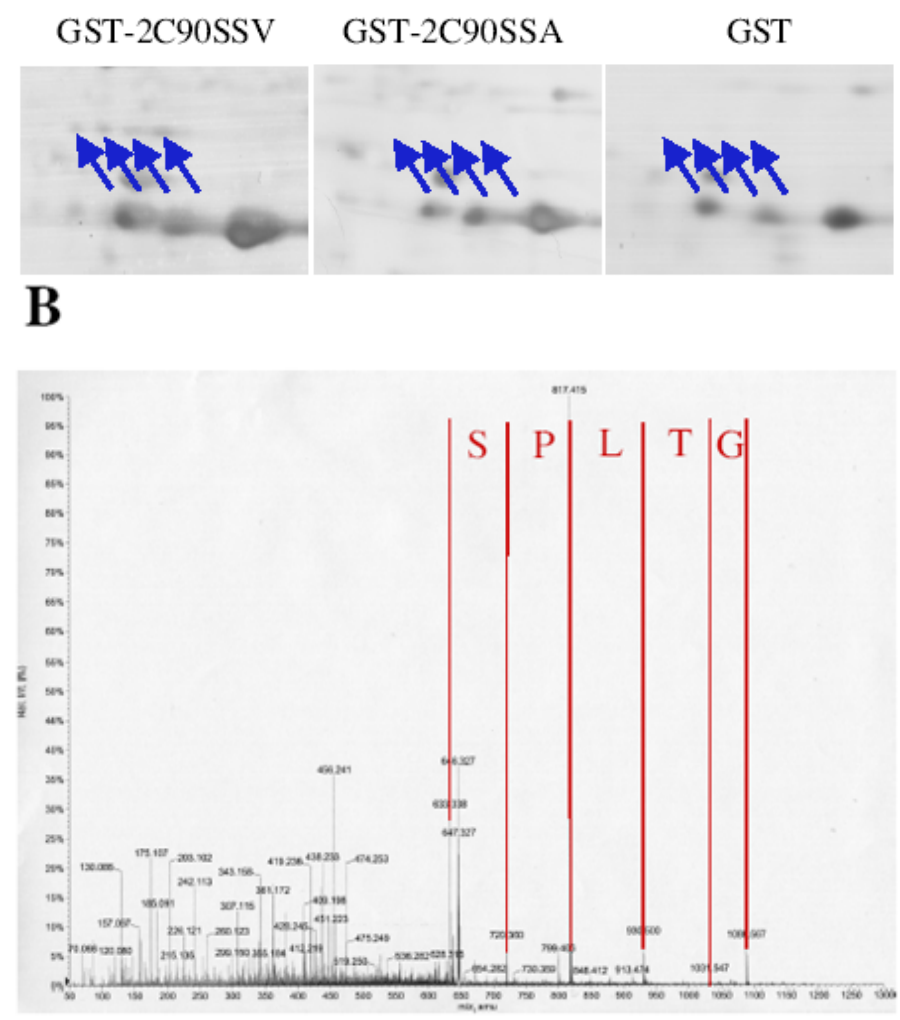


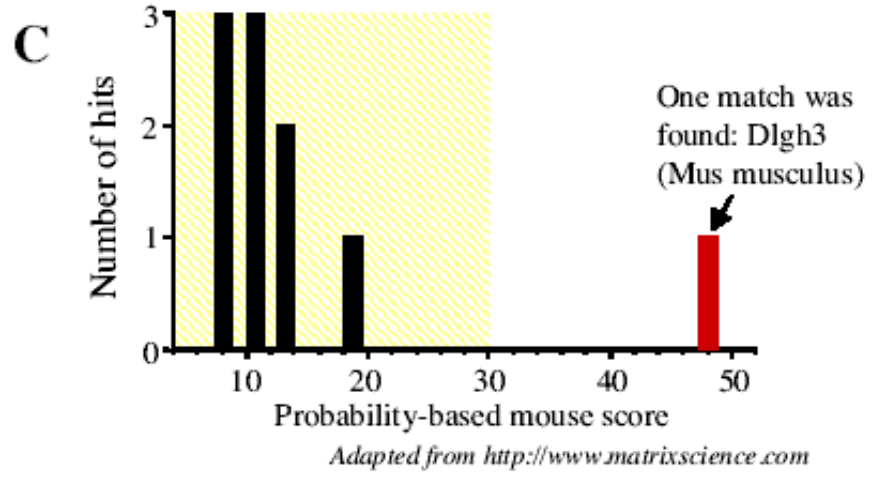

D Search parameters

\begin{tabular}{|c|c|}
\hline Sequence Tag & (203/98 1)GTLPS(658.319) \\
\hline Prokein mas ange & $0-300 \mathrm{kDa}$ \\
\hline Emzyme & Trypsin \\
\hline Pepkide mass accuracy & $2 \mathrm{Da}$ \\
\hline Methionine is & Native \\
\hline Cysteine is & Carbamidometryl-Cys \\
\hline Peptide mas & 1289.651 \\
\hline Match regions & 1,2 and 3 \\
\hline Search by & Btype sequence ions \\
\hline Allow mimber of errors & 0 \\
\hline Nominal mass & Isolexxine eqpols kewine \\
\hline Nominal mass & Ghatumine equals lysine \\
\hline N kerminal specific & Yes \\
\hline C termind specific & Yes \\
\hline
\end{tabular}

Search results: one match was found

\begin{tabular}{|c|c|c|c|}
\hline Peptide sequence matched & Mass (Da) & Aceession number & Protein name \\
\hline TTGTLPSPQNFK & 64.47 & 088910 & Dlgh3 (Mus musculus) \\
\hline
\end{tabular}

Adapted from http://www.narrador embl-heidelberg de

Fig. 3: Tandem mass spectrometry identification of Dlgh3 as a binding partner of the PDZ ligand of the 5-HT $2 \mathrm{C}$ receptor. A. Areas of interest of silver-stained 2-D gels obtained in experiments using the GST902CSSV, GST902CSSA and GST baits, respectively, and showing the specific recruitment of four protein spots (indicated by arrows) by the PDZ ligand of the $5-\mathrm{HT}_{2 \mathrm{C}}$ receptor. These spots were identified as a single protein by MALDI-TOF MS (not shown). B. Fragmentation spectrum of a double charged ion at $\mathrm{m} / \mathrm{z}=645.80$ detected on the nanoelectrospray mass spectrum of the tryptic digestion product of one of these spots. A sequence of five amino acids is apparent in the higher mass part of the spectrum. C. Graphical representation of hits obtained by matching the fragmentation spectrum illustrated in B. and the calculated spectra of all the peptides in the $\mathrm{NCBr}$ database. D. Parameters and results of Non-Redundant Database search using the peptide sequence tag method. Both methods yielded a single match with a mouse Dlgh3 peptide.

Our procedure using silver staining of 2-D gels allows the detection of proteins recruited in relatively low amounts (a few ng) in the affinity chromatography step. The sensitivity of silver staining allows full use of the sensitivity of current MALDI-TOF and Quadrupole-TOF mass spectrometers like those used in our study. In this regard, the intensities of ion signals detected by MALDI-TOF mass spectrometry in digests of small protein spots (such as those identified as Dlgh3) were in the same range as those obtained with a mixture of external peptide calibrates (50-100 fmol each). However, the low dynamic range and the rapid saturation of silver staining only allow semi-quantitative measurements of proteins detected on 2-D gels. Other staining procedures using fluorescent dyes (e.g. Sypro Ruby), that are just as sensitive as silver staining, would certainly provide more quantitative information without precluding further identification of proteins by mass spectrometry.

Despite the reasonably high sensitivity of silver staining, we failed to detect some of the binding partners of the receptor, in particular those that indirectly interact with its $\mathrm{C}$-terminal extremity. This critical limitation for a global characterization of multiprotein complexes cannot be overcome by increasing the amount of proteins loaded on the 2-D gels. Indeed, due the high amount of GST baits in the samples, compared with the other proteins, overloading the gels would alter the electrofocusing of proteins during the first dimension. To identify additional protein components of the complexes purified by affinity chromatography, we combined mass spectrometry with immunoblotting screens. These immunoblotting screens were based on the data of the literature on the known partners of the proteins previously identified by mass spectrometry analyzes. For example, the Veli proteins are known to be part of ternary protein complexes also composed of CASK, a membrane-associated guanylate kinase that contains one PDZ domain, and Mint1, a modular protein that contains two PDZ domains $(24,25)$. Immunoblotting experiments performed with a CASK and a Mint1 antibody after the affinity chromatography step showed that both CASK and Mint 1 were recruited by the C-terminal extremity of the 5$\mathrm{HT}_{2 \mathrm{C}}$ receptor (12). This suggests that the $5-\mathrm{HT}_{2 \mathrm{C}}$ receptor interacts with the entire ternary complex Veli3-CASK-Mint1. CASK is known to interact with both Veli proteins and Mint1. These interactions do not involve PDZ domains, which are free to interact with additional protein partners (24). Several pieces of evidence indicate that the ternary complex Veli3-CASKMint1 interacts with the 5- $\mathrm{HT}_{2 \mathrm{C}}$ receptor through Veli3 and, thus, that CASK and Mint1 are indirect partners. 1) Only Veli3 was detected by silver staining, indicating that lower amounts of CASK and Mint1 were recruited. 2) Veli3 and the 5- $\mathrm{HT}_{2 \mathrm{C}}$ receptor interacted in heterologous cells (12). 3) The PDZ domain of Veli3 is class I, which determines optimal binding to the PDZ ligand of the 5- $\mathrm{HT}_{2 \mathrm{C}}$ receptor. In contrast, the PDZ domain of CASK is class II, which renders improbable its direct binding to the PDZ ligand of the 5- $\mathrm{HT}_{2 \mathrm{C}}$ receptor (7). This example illustrates how immunoblotting associated with mass spectrometry may be useful to detect low amounts of proteins in a complex such as proteins indirectly associated with a receptor.

One important issue concerns the specificity of the protein complexes identified by our fishing approach. Coimmunoprecipitation experiments performed with some of the binding partners of the 5- $\mathrm{HT}_{2 \mathrm{C}}$ receptor indicated for all the proteins tested that the receptor interacts with them in the mouse CNS (12). Moreover, immunohistochemistry and electron microscopy experiments revealed a similar distribution of these proteins and the 5- $\mathrm{HT}_{2 \mathrm{C}}$ receptor in CNS cells. Finally, we have used a similar approach to identify the protein complexes interacting with the C-terminal extremities of three other 5-HT receptors that express PDZ-like ligands (namely the $5-\mathrm{HT}_{2 \mathrm{~A}}$ receptor and two splice variants of the $5-\mathrm{HT}_{4}$ receptor). The four complexes examined showed different protein composition (unpublished results). 


\section{CONCLUSIONS}

We have established a specific and sensitive method to purify and identify the proteins that interact directly or indirectly with the C-terminal extremity of GPCRs. This approach may be used to characterize the multiprotein complexes interacting with the intracellular domains of any membrane-bound receptors and, more generally, the protein complexes associated with any intracellular protein.

\section{ACKNOWLEDGMENTS}

This work was supported by grants from the CNRS, the Génopole de Montpellier and the Région LanguedocRoussillon. C. Bécamel was a recipient of a fellowship from the Association pour la Recherche contre le Cancer.

\section{REFERENCES}

1. Husi H, Ward MA, Choudhary JS, Blackstock WP, Grant SG. Proteomic analysis of NMDA receptor-adhesion protein signaling complexes. Nat Neurosci 2000;3:661669.

2. Kim M, Jiang LH, Wilson HL, North RA, Surprenant A. Proteomic and functional evidence for a $\mathrm{P} 2 \mathrm{X}(7)$ receptor signalling complex. Embo J 2001;20:6347-6358.

3. Brzostowski JA, Kimmel AR. Signaling at zero G: Gprotein-independent functions for 7-TM receptors. Trends Biochem Sci 2001;26:291-297.

4. Milligan G, White J. Protein-protein interactions at Gprotein-coupled receptors. Trends Pharmacol Sci 2001;22:513-518.

5. Brady AE, Limbird LE. G protein-coupled receptor interacting proteins: emerging roles in localization and signal transduction. Cell Signal 2002;14:297-309.

6. Bockaert J, Claeysen S, Bécamel C, Pinloche S, Dumuis A. $\mathrm{G}$ protein-coupled receptors: dominant players in cellcell communication. Int Rev Cytol 2002;212:63-132.

7. Sheng M, Sala C. PDZ domains and the organization of supramolecular complexes. Annu Rev Neurosci 2001;24:129.

8. Hall RA, Premont RT, Chow CW, Blitzer JT, Pitcher JA, Claing A, Stoffel RH, Barak LS, Shenolikar S, Weinman EJ, Grinstein S, Lefkowitz RJ. The beta2- adrenergic receptor interacts with the $\mathrm{Na}+/ \mathrm{H}+$-exchanger regulatory factor to control $\mathrm{Na}+\mathrm{H}+$ exchange. Nature 1998;392:626630.

9. Ullmer C, Schmuck K, Figge A, Lubbert H. Cloning and characterization of MUPP1, a novel PDZ domain protein. FEBS Lett 1998;424:63-68.

10. Zitzer H, Honck HH, Bachner D, Richter D, Kreienkamp HJ. Somatostatin receptor interacting protein defines a novel family of multidomain proteins present in human and rodent brain. J Biol Chem 1999b;274:32997-33001.

11. Raymond JR, Mukhin YV, Gelasco A, Turner J, Collinsworth G, Gettys TW, Grewal JS, Garnovskaya MN. Multiplicity of mechanisms of serotonin receptor signal transduction. Pharmacol Ther 2001;92:179-212.

12. Bécamel C, Alonso G, Galeotti N, Demey E, Jouin P, Ullmer C, Dumuis A, Bockaert J, Marin P. Synaptic multiprotein complexes associated with 5-HT(2C) receptors: a proteomic approach. Embo J 2002;21:23322342.

13. Misawa H, Kawasaki Y, Mellor J, Sweeney N, Jo K, Nicoll RA, Bredt DS. Contrasting localizations of MALS/LIN-7 PDZ proteins in brain and molecular compensation in knockout mice. $J$ Biol Chem 2001;276:9264-9272.

14. Bécamel C, Figge A, Poliak S, Dumuis A, Peles E, Bockaert J, Lubbert H, Ullmer C. Interaction of serotonin 5-hydroxytryptamine type $2 \mathrm{C}$ receptors with PDZ10 of the multi-PDZ domain protein MUPP1. J Biol Chem 2001;276:12974-12982.

15. Laoudj-Chenivesse D, Marin P, Bennes R, Tronel-Peyroz E, Leterrier F. High performance two-dimensional gel electrophoresis using a wetting agent Tergitol(R) NP7. Proteomics 2002;2:481-485.

16. Shevchenko A, Wilm M, Vorm O, Mann M. Mass spectrometric sequencing of proteins silver-stained polyacrylamide gels. Anal Chem 1996;68:850-858.

17. Lee K, Bae D, Lim D. Evaluation of parameters in peptide mass fingerprinting for protein identification by MALDITOF mass spectrometry. Mol Cells 2002;13:175-184.

18. Karas M, Hillenkamp F. Laser desorption ionization of proteins with molecular masses exceeding 10,000 daltons. Anal Chem 1988;60:2299-2301.

19. Garin J, Diez R, Kieffer S, Dermine JF, Duclos S, Gagnon E, Sadoul R, Rondeau C, Desjardins M. The phagosome proteome: insight into phagosome functions. $J$ Cell Biol 2001;152:165-180.

20. Mann M, Wilm M. Error-tolerant identification of peptides in sequence databases by peptide sequence tags. Anal Chem 1994;66:4390-4399.

21. Mann M, Hendrickson RC, Pandey A. Analysis of Proteins and Proteomes by Mass Spectrometry. Annu Rev Biochem 2001;70:437-473.

22. Ficarro SB, McCleland ML, Stukenberg PT, Burke DJ, Ross MM, Shabanowitz J, Hunt DF, White FM. Phosphoproteome analysis by mass spectrometry and its application to Saccharomyces cerevisiae. Nat Biotechnol 2002;20:301-305.

23. Jo K, Derin, R, Li, M , Bredt, DS. Characterization of MALS/Velis-1, -2, and -3: a family of mammalian LIN- 7 homologs enriched at brain synapses in association with the postsynaptic density-95/NMDA receptor postsynaptic complex. J Neurosci 1999;19:4189-4199.

24. Butz S, Okamoto, M , Südhof, TC. A tripartite protein complex with the potential to couple synaptic vesicle exocytosis to cell adhesion in brain. Cell 1998;94:773-782.

25. Borg JP, Straight, SW, Kaech, SM, de Taddeo-Borg, M, Kroon, DE, Karnak, D, Turner, RS, Kim, SK , Margolis, B. Identification of an evolutionarily conserved heterotrimeric protein complex involved in protein targeting. $J$ Biol Chem 1998;273:31633-31636. 


\section{PROTOCOLS}

\section{Production and immobilization of GST fusion proteins}

\section{Solutions and media:}

- SOC medium: $2 \%$ tryptone, $0.5 \%$ yeast extract, $10 \mathrm{mM} \mathrm{NaCl}, 2.5 \mathrm{mM} \mathrm{KCl}, 10 \mathrm{mM} \mathrm{MgCl}$ and $20 \mathrm{mM}$ glucose

- SOB-ampicillin medium: $2 \%$ tryptone, $0.5 \%$ yeast extract, $10 \mathrm{mM} \mathrm{NaCl}, 2.5 \mathrm{mM} \mathrm{KCl}, 10 \mathrm{mM} \mathrm{MgCl}{ }_{2}$ and $100 \mu \mathrm{g} / \mathrm{ml}$ ampicillin

- LB-ampicillin plate: $1 \%$ tryptone, $0.5 \%$ yeast extract, $1 \% \mathrm{NaCl}, 10 \mathrm{mM} \mathrm{MgCl}_{2}, 100 \mu \mathrm{g} / \mathrm{ml}$ ampicillin and $1.3 \%$ agar

- Cell lysis solution: phosphate buffered saline (PBS), $0.5 \mathrm{mM}$ DTT and a protease inhibitor cocktail (Roche)

\section{Protocol:}

1. Transfer $1 \mathrm{ng}$ of plasmid DNA in $25 \mu \mathrm{l}$ of BL21 competent cell suspension. Stir gently to mix. Incubate successively at $0^{\circ} \mathrm{C}$ for $30 \mathrm{~min}$, at $42^{\circ} \mathrm{C}$ for $30 \mathrm{sec}$ and then at $0^{\circ} \mathrm{C}$ for $2 \mathrm{~min}$

2. Add $500 \mu \mathrm{l}$ of SOC medium. Incubate at $37^{\circ} \mathrm{C}$ for $1 \mathrm{~h}$ with shaking

3. Plate $200 \mu \mathrm{l}$ of BL21 cell suspension on LB-ampicillin. Incubate overnight at $37^{\circ} \mathrm{C}$

4. Remove a single colony and culture in $50 \mathrm{ml}$ of SOB-ampicillin medium overnight at $37^{\circ} \mathrm{C}$

5. Add $450 \mathrm{ml}$ of SOB-ampicillin medium and culture at $37^{\circ} \mathrm{C}$ until $\mathrm{OD}_{600 \mathrm{~nm}}=0.5$

6. Induce synthesis of recombinant proteins by adding $0.25 \mathrm{mM}$ isopropyl- $\beta-\mathrm{D}$-thiogalactopyranoside for $3 \mathrm{~h}$ at $37^{\circ} \mathrm{C}$

7. Harvest cells by centrifugation at $1,000 \mathrm{x}$ g for $15 \mathrm{~min}$ at $4^{\circ} \mathrm{C}$

8. Suspend completely the cell pellet in $25 \mathrm{ml}$ cell lysis solution and sonicate on ice 5 times for $1 \mathrm{~min}$

9. Add $1 \%$ Triton $\mathrm{X} 100$ and leave samples in rotation at $4^{\circ} \mathrm{C}$ for $1 \mathrm{~h}$

10. Centrifuge at $12,000 \mathrm{xg}$ for $10 \mathrm{~min}$ at $4^{\circ} \mathrm{C}$. Keep the surpernatant. The amount of recombinant protein can be estimated by SDS-PAGE of an aliquot using bovine serum albumin as standard.

11. Incubate $50 \mu \mathrm{g}$ of each GST-fusion protein with $500 \mu \mathrm{l}$ of glutathione Sepharose beads for $1 \mathrm{~h}$ in rotation at $4^{\circ} \mathrm{C}$

12. Wash beads 3 times with PBS

\section{Preparation of CHAPS-soluble brain extracts}

\section{Solutions:}

- Lysis buffer: $50 \mathrm{mM}$ Tris-HCl, $\mathrm{pH} 7.4,1 \mathrm{mM}$ EDTA and the protease inhibitor cocktail

- Solubilization buffer: $50 \mathrm{mM}$ Tris-HCl, pH 7.4, $0.05 \mathrm{mM}$ EDTA, $10 \mathrm{mM}$ CHAPS and the protease inhibitor cocktail

\section{Protocol:}

1. Dissect 2 mice brains per condition and homogenize with a polytron in $10 \mathrm{ml}$ PBS. Centrifuge at $200 \mathrm{xg}$ for $5 \mathrm{~min}$

2. Suspend the pellet in $2 \mathrm{ml}$ ice-cold lysis buffer $/ 2$ mice brains and homogenize 20 times on ice with a glass-Teflon homogenizer. Centrifuge at $10,000 \mathrm{x}$ g for $30 \mathrm{~min}$ at $4^{\circ} \mathrm{C}$

3. Suspend membrane pellet in $2 \mathrm{ml}$ solubilization buffer and homogenize 5 times on ice with a glass-Teflon homogenizer. Leave samples on rotation for $3 \mathrm{~h}$ at $4^{\circ} \mathrm{C}$

4. Centrifuge at $10,000 \mathrm{x}$ g for $1 \mathrm{~h}$ at $4^{\circ} \mathrm{C}$. Keep the supernatant (solubilized proteins)

\section{GST pull-down}

1. Incubate solubilized proteins of 2 mice brains with immobilized GST fusion proteins overnight in rotation at $4{ }^{\circ} \mathrm{C}$

2. Wash beads 5 times with $0.5 \mathrm{M} \mathrm{NaCl}$

3. Incubate beads with $10 \mathrm{mM}$ reduced glutathione for $1 \mathrm{~h}$ in rotation at $4{ }^{\circ} \mathrm{C}$

4. Centrifuge at $1,000 \mathrm{x}$ g for $10 \mathrm{~min}$ at $4^{\circ} \mathrm{C}$. Keep the supernatant

5. Precipitate proteins with $10 \%$ ice-cold TCA for $2 \mathrm{~h}$ on ice

6. Centrifuge at $10,000 \mathrm{xg}$ for $15 \mathrm{~min}$ at $4^{\circ} \mathrm{C}$

7. Wash the TCA precipitates 3 times with $1 \mathrm{ml}$ diethyl ether 


\section{Two-dimensional electrophoresis}

\section{Materials:}

First dimension: IPGPhor + strip holders (18 cm long, Amersham Biosciences)

Second dimension: Etan-Dalt II (Amersham Biosciences)

\section{Solutions:}

- Isoelectrofocusing medium: $7 \mathrm{M}$ urea, $2 \mathrm{M}$ thiourea, 4\% CHAPS, ampholines (preblended, pI 3.5-9.5, $8 \mathrm{mg} / \mathrm{ml}$ ), $100 \mathrm{mM}$ DTT, $0.2 \%$ Tergitol NP7 and traces of bromophenol blue

- Equilibration medium with DTT: $50 \mathrm{mM}$ Tris-HCl, $\mathrm{pH}$ 6.8, 30\% glycerol, 2\% SDS, $10 \mathrm{mg} / \mathrm{ml}$ DTT and traces of bromophenol blue

- Equilibation medium with iodoacetamide: $50 \mathrm{mM}$ Tris-HCl, $\mathrm{pH} 8.8,30 \%$ glycerol, $2 \% \mathrm{SDS}, 15 \mathrm{mg} / \mathrm{ml}$ iodoacetamide and traces of bromophenol blue

- Polycrylamide gel mixture: $12.5 \%$ acrylamide (Plus One, Amersham Biosciences), $0.16 \%$ bisacrylamide (Plus One), $375 \mathrm{mM}$ Tris-HCl, $\mathrm{pH} 8.8,0.1 \%$ SDS, $0.015 \%$ ammonium persulfate and $0.05 \%$ TEMED

- Agarose solution: $1 \%$ agarose (low-melting), $150 \mathrm{mM}$ Tris-HCl, $\mathrm{pH}$ 6.8, 0.2\% SDS

\section{Protocol:}

1. Suspend the TCA precipitates in $350 \mu$ isoelectrofocusing medium.

2. Apply the sample between the electrodes of a strip holder.

3. Add a pre-casted IPG dry strip (pH 3-10, linear, $18 \mathrm{~cm}$ long, Amersham Biosciences).

4. Recover with $1 \mathrm{ml}$ mineral oil.

5. Perform the isoelectrofocusing with the following parameters and steps: $20^{\circ} \mathrm{C}, 50 \mu \mathrm{A}$ per strip, rehydration period, $12 \mathrm{~h}$; gradient $0-300 \mathrm{~V}, 1 \mathrm{~min}$; step-and-hold $300 \mathrm{~V}, 30 \mathrm{~min}$; gradient $300-5000 \mathrm{~V}, 3 \mathrm{~h}$; step-and-hold $5000 \mathrm{~V}, 40,000 \mathrm{~V} / \mathrm{h}$. The strips can be kept for several months at $-80^{\circ} \mathrm{C}$ after isoelectrofocusing.

6. Incubate the strip for 10 min with $6 \mathrm{ml}$ equilibration medium with DTT.

7. Remove the excess of DTT on the strip.

8. Incubate the strip for $15 \mathrm{~min}$ with $6 \mathrm{ml}$ equilibration medium with iodoacetamide.

9. Load the strip on the top of a $12.5 \%$ polyacrylamide gel $(20 \times 20 \mathrm{~cm}, 1 \mathrm{~mm}$ thick).

10. Seal the strip with $1-2 \mathrm{ml}$ agarose solution (heated at $60^{\circ} \mathrm{C}$ ).

11. Perform the second dimension in two steps: 1) $1 \mathrm{~h}$ at $60 \mathrm{~V}$ and $45 \mathrm{~mA}$ per gel (an initial low-voltage step reduces electroendosmosis); 2) $5 \mathrm{~h}$ at $300 \mathrm{~V}, 45 \mathrm{~mA}$ per gel.

\section{Silver staining}

1. Fix the gel in ethanol:acetic acid (50:5\% in distilled water) for $20 \mathrm{~min}$.

2. Incubate the gel in $50 \%$ ethanol for $10 \mathrm{~min}$.

3. Wash the gel with distilled water for $10 \mathrm{~min}$.

4. Incubate the gel with sodium thiosulfate $(0.02 \%)$ for $1 \mathrm{~min}$.

5. Wash the gel for $10 \mathrm{sec}$ twice with distilled water.

6. Stain the gel with $\mathrm{AgNO}_{3}(1 \mathrm{~g} / \mathrm{l})$ for $20 \mathrm{~min}$ at $4^{\circ} \mathrm{C}$.

7. Wash the gel for $10 \mathrm{sec}$ twice with distilled water.

8. Incubate the gel with the developing solution $\left(40 \mathrm{~g} / 1 \mathrm{Na}_{2} \mathrm{CO}_{3}, 0.1 \%\right.$ formaldehyde). Change rapidly the developing solution after a yellow precipitate appears and incubate the gel with the new solution until appropriate staining is achieved.

9. Stop the revelation by replacing the developing solution by $5 \%$ acetic acid.

10. Store the gel in $1 \%$ acetic acid at $4^{\circ} \mathrm{C}$ (the gels can be stored for a few weeks before digestion).

\section{Image acquisition and two-dimensional protein pattern analysis}

1. Scan the gels with a computer-assisted densitometer (such as the ImageScanner, Amersham Biosciences, etc.).

2. Detect protein spots in the gels to be processed with a 2-D gel analysis software (such as Image Master 2D Elite, Amersham 
Biosciences, etc.).

3. Suppress dark noise.

4. Match the corresponding spots in the gels to be processed and perform gel alignment.

5. Perform spot quantification (expressed as spot volume relative to either the volume of all spots in each gel or the volume of a single spot found in equal amount in all experimental conditions, to correct for variability resulting from silver staining).

6. Calculate mean values from at least 4 gels performed from different pull down experiments and perform the appropriate statistical tests.

\section{In-gel protein digestion with trypsin}

1. Excise carefully pieces of gels including the spots to be processed, cut them in 1-mm large pieces and transfer them to $0.5 \mathrm{ml}$ polypropylene tubes. Cut a control piece of gel from a blank region of the gel and process it in parallel with the samples.

2. Shrink the gel pieces by dehydration with acetonitrile for $10 \mathrm{~min}$ (in this step as in the following ones, use the minimal solution volume required to recover the gel pieces) and remove the liquid phase.

3. Swell the gel pieces by rehydration with $100 \mathrm{mM} \mathrm{NH} \mathrm{HCO}_{3}$ for $10 \mathrm{~min}$.

4. Dehydrate the gel pieces with acetonitrile and remove the liquid phase.

5. Dry the gel pieces in a vacuum centrifuge for $5 \mathrm{~min}$.

6. Swell the gel pieces with the digestion buffer (100 $\mathrm{mM} \mathrm{NH}_{4} \mathrm{HCO}_{3}, 5 \mathrm{mM} \mathrm{CaCl}_{2}$ and 150 ng trypsin per 2-100 ng protein spot) on ice for $45 \mathrm{~min}$.

7. Add the same volume of the digestion buffer, but without trypsin, to keep the gel pieces wet during the digestion period $\left(25^{\circ} \mathrm{C}\right.$, overnight).

8. Transfer the liquid phase to a $1.5 \mathrm{ml}$ polypropylene tube.

9. Dehydrate the gel pieces with acetonitrile for $10 \mathrm{~min}$ and transfer the liquid phase to the same $1.5 \mathrm{ml}$ tube.

10. Swell the gel pieces by rehydration with $100 \mathrm{mM} \mathrm{NH}_{4} \mathrm{HCO}_{3}$ for $10 \mathrm{~min}$.

11. Dehydrate the gel pieces with acetonitrile for $10 \mathrm{~min}$ and transfer the liquid phase to the same $1.5 \mathrm{ml}$ tube.

12. Renew 10 and 11.

13. Swell the gel pieces by rehydration with $5 \%$ formic acid for $10 \mathrm{~min}$.

14. Dehydrate the gel pieces with acetonitrile for $10 \mathrm{~min}$ and transfer the liquid phase to the same $1.5 \mathrm{ml}$ tube.

15. Renew 13 and 14.

16. Dry peptide samples with a vacuum centrifuge.

\section{Sample preparation for MALDI-TOF analysis}

1. Dissolve the peptide mixture in $10 \mu \mathrm{l}$ formic acid $(2 \%)$.

2. Desalt the peptide mixture using Zip Tips C18 according to the manufacturer's procedure.

3. Elute peptides with $10 \mu \mathrm{l}$ of acetonitrile:trifluoroacetic acid (80:0.1\%) and concentrate by evaporation to $2 \mu 1$.

4. Mix $0.5 \mu \mathrm{l}$ of analyte solution with the same volume of matrix (10 mg $\alpha$-cyano-4-hydroxy-trans-cinnamic acid in $1 \mathrm{ml}$ of acetonitrile:trifluoroacetic acid, 50:0.1\%).

5. Deposit $0.3 \mu \mathrm{l}$ of this mixture on a stainless steel target.

6. Evaporate the solvent.

7. Introduce the target in the mass spectrometer.

\section{MALDI-TOF mass spectra interpretation and database interrogation}

1. Calibrate the mass spectra using the auto-proteolysis products of trypsin $(m / z 842.51,1045.56,2211.10)$ as internal calibrates using an appropriate software (e.g. the XTOF software, Bruker, etc.).

2. Select mono isotopic peptides in the mass range of 800-3500 Da.

3. Remove contaminating peptides from the mass list (peptides found in the control digestion performed on a blank region of the gel).

4. Search database with the resulting peptide mass list using an appropriate software (such as Mascot or Peptident).

\section{Micro purification of peptides for tandem mass spectrometry}

1. Suspend $2 \mu \mathrm{l}$ of POROS R2 sorbent (PerSeptive Biosystems) in 50\% methanol.

2. Load suspension in a capillary (Protana Inc.) using Gel loader tips. 
3. Centrifuge the capillary using the purification device.

4. Wash the micro column with $5 \mu$ methanol:formic acid (50:5\%) and store in $10 \mu \mathrm{l}$ formic acid (5\%). A new capillary with new POROS must be used for each analysis.

5. Dissolve peptide mixture in $5 \mu \mathrm{l}$ formic acid (5\%) and load onto the micro column.

6. Centrifuge the capillary using the purification device.

7. Wash the peptides on the column with $5 \mu \mathrm{l}$ formic acid (5\%).

8. Align a nano Electrospray (nanoES) capillary (ES380-ES382, Protana Inc) in continuation of the micro column.

9. Elute the peptides into the nanoES capillary twice with $0.5 \mu \mathrm{l}$ methanol:formic acid (50:5\%).

10. Place the nanoES capillary in the nanoES source head.

\section{Tandem mass spectra interpretation and database searching}

1. Select double charged ions in the MS spectrum and fragment them by MS/MS.

2. Perform database search with the mass lists from MS/MS spectra of multiple peptides from the same protein using the Mascot software (http://www.matrixscience.com).

3. Combine the mass of the precursor peptide, the mass of the first peak of an identified sequence ladder, the sequence ladder and the final peak of the sequence ladder to obtain a peptide sequence tag (21). The ladder is obtained manually by starting from the highest $\mathrm{m} / \mathrm{z}$ of a $\mathrm{Y}$ ion series of the MS/MS spectrum using an appropriate software (e.g. BioAnalyst, Applied Biosystems).

4. Perform database search with this tag using the PeptideSearch software (http://www.narrador.embl-heidelberg.de).

5. Compare results in 2 and 4 . 